\title{
Development of Energy Storage Systems for Power Network Reliability: A Review
}

\author{
Farihan Mohamad ${ }^{1}$, Jiashen Teh ${ }^{1, *}(\mathbb{D})$, Ching-Ming Lai ${ }^{2}$ (D) and Liang-Rui Chen ${ }^{3}$ \\ 1 School of Electrical and Electronic Engineering, Universiti Sains Malaysia (USM), \\ Nibong Tebal 14300, Malaysia; farihan.mohamad@student.usm.my \\ 2 Department of Vehicle Engineering, National Taipei University of Technology, 1, Sec. 3, \\ Chung-Hsiao E. Road, Taipei 106, Taiwan; pecmlai@gmail.com \\ 3 Department of Electrical Engineering, National Changhua University of Education, No. 1, Jinde Rd., \\ Changhua City 50007, Taiwan; lrchen@cc.ncue.edu.tw \\ * Correspondence: jiashenteh@usm.my; Tel.: +60-4-599-6016
}

Received: 6 August 2018; Accepted: 27 August 2018; Published: 30 August 2018

\begin{abstract}
Electricity plays a crucial role in the well-being of humans and is a determining factor of the economic development of a country. Electricity issues have encouraged researchers to focus on improving power availability and quality along with reliability. This pursuit has increasingly raised the intention to integrate renewable energy (RE) into power systems to curb the problem of energy deficiency. However, intermittency in the sources of RE supply coupled with fluctuating changes in demand with respect to time has induced high risk in maintaining system reliability in terms of providing adequate supply to consumers. Whilst an energy storage system (ESS) is not another source of electricity, it is proven to be effective and viable in solving the aforementioned issues. Thus, this paper comprehensively reviews the development of ESS technologies and discusses the benefits and real-life applications of these technologies. The concept of reliability in power systems is also explored to provide an improved understanding of this study. Lastly, notable studies that have addressed the reliability impact of ESSs on power systems are discussed. This review paper therefore is expected to provide a critical analysis of ESS developments, as well as recognize their research gaps in terms of reliability studies in modern RE-integrated power networks.
\end{abstract}

Keywords: energy storage system; power system reliability; renewable energy; smart grid

\section{Introduction}

Sustainable development is currently a crucial issue globally. The most common and simplest definition of sustainable development is "development that meets the needs of the present without compromising the ability of future generations to meet their own needs" [1]. There are many factors that can contribute to achieving sustainable development. One of them is to be able to supply energy sources that are fully sustainable [2]. A secure supply is a necessity; however, it also must comply with other considerations to achieve sustainable development. Energy is expected to be readily available all the time, at reasonable costs, and without causing negative societal impacts [3].

Conventional energy sources based on oil, coal, and natural gas have contributed the most towards the development we have achieved today. However, excessive use of these sources is causing depletion of these reserves, as well as damaging the environment and humans' health [4]. These so-called "dirty sources" are facing increasing pressure from environmental advocates, becoming targets of Kyoto Protocol greenhouse gas reduction. The challenges in meeting energy demand whilst limiting greenhouse gases have prompted the idea of integrating renewable energy (RE) sources into power systems. RE has been recognised in tackling issues such as energy access and energy security. 
Many initiatives have been undertaken especially in developing counties to improve accessibility, with the help of stand-alone RE generation to meet the demand of rural communities in a cheaper and cleaner way [5]. Energy security, on the other hand, refers to secured supply of energy without compromising any disruptions. Since the majority of power generation comes from fossil fuel, energy security is harmed by price volatility [6]. Local RE options can mitigate this problem by diversifying supply options and reducing dependency on imported energy supply [5].

Whilst RE sources are offering such great benefits, these inexhaustible sources are also characterised by fluctuating generated power output. Therefore, high penetration of RE sources into power grids may risk power system stability due to their intermittency in nature. Power oscillations due to intermittency may also cause rapid voltage fluctuations, which can damage the equipment [7]. Energy storage systems (ESSs) can contribute to improving system reliability whilst optimally maintaining sensible operational costs in the aforementioned case. ESSs can mitigate power variations and functions as storage for flexible dispatch of RE.

Following the definition obtained from [8,9], ESSs enable the method of converting electrical energy from power grids into a form that can be stored for utilising the energy when needed. Therefore, the ESS will dispatch its stored energy during low energy production of RE, and will help store excess energy when power production is high. Apart from supporting this type of generation, ESSs can also mitigate some issues in the conventional generation sector, such as peak shaving and energy arbitrage $[10,11]$. In other words, an ESS is a flexible power electronic device that supports the grid in providing a constant supply whilst satisfying power quality and reliability [12,13].

In the electric utility industry, power outage is the main concern because consumers are expecting a continuous ready supply throughout the year. This ready supply is termed as "reliability", which is further defined as the reliability of a power system to provide adequate output to consumers, as discussed in [14]. Approaches to evaluating the reliability of a power system are available at different levels, namely, generation, composite generation, and distribution. Reliability evaluation provides utility in decision-making and future planning for the best optimisation solution.

The rest of the paper is structured as follows. Section 2 describes the services offered by ESSs and their real-life applications. Section 3 presents the concept of power system reliability and discusses a number of research publications related to ESS contributions to power system reliability. Section 4 provides a discussion on overall findings that can be summarised from the review. Lastly, Section 5 elaborates the conclusions and potential future works.

\section{Energy Storage Systems}

\subsection{Applications and Benefits of ESSs}

The adoption of ESSs in utility grids is a smart move in mitigating power system issues from large-scale application of generation and transmission networks to small-scale application of distribution networks and microgrids. Services offered by ESSs are numerous and expected to advance in the future. Reference [15] classified the usage and benefits of the system into five categories: bulk energy, ancillary, transmission infrastructure, distribution structure, and energy management services. Figure 1 summarises the five subdivisions of power grid solutions that can be offered by an ESS. These applications will be further discussed in accordance with Figure 1. 


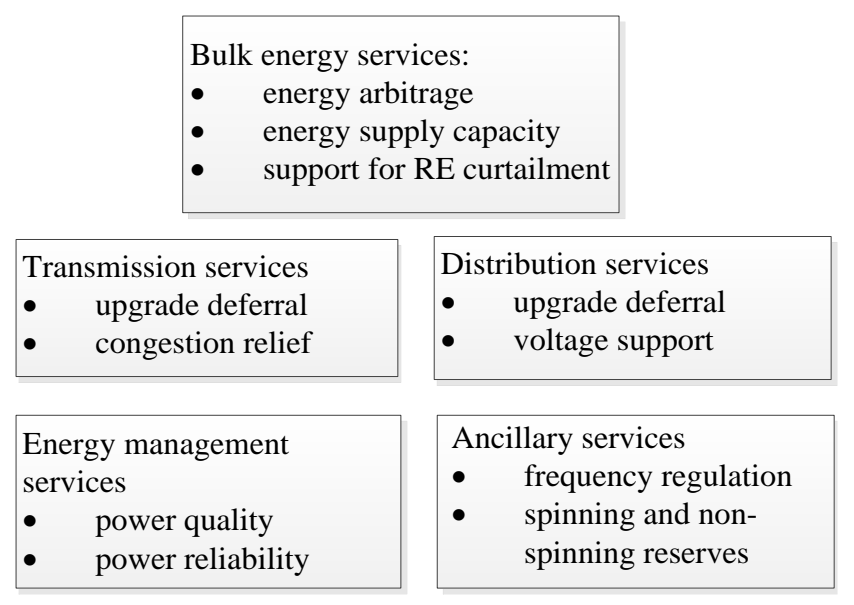

Figure 1. Applications of energy storage systems (ESSs).

\subsubsection{Bulk Energy Services}

As shown in Figure 1, three benefits can be generally obtained from an ESS under a bulk energy service. The first one is energy arbitrage. An ESS enables flexibility by storing bulk energy in certain periods for use during peak demand to arbitrage the production price of the two periods for providing a uniform load factor [10]. Generation systems are installed in accordance with the anticipated peak demand. Hence, they can be over-priced due to over-estimation. The installation cost of a generator is based on its rated capacity and often influenced by peak demand. Therefore, wastage occurs because peak demand does not happen all the time. Therefore, an ESS can potentially curb this problem by providing additional supply capacity during peak demand and reduce the need for installing high-capacity generation systems [9]. Lastly, the development of RE to curb environmental issues and provide an inexhaustible supply has induced considerable interest amongst power system engineers to integrate an ESS into the system to relieve the fluctuation in the output power generated by these sources [16].

\subsubsection{Transmission Services}

The world population is increasing annually, and the rapidly advancing economic development always results in high electricity demand. The International Energy Agency (IEA) reported in 2014 that approximately 13,371 Mtoe of energy was supplied cumulatively in 2012, showing a 10\% increase in load demand over only a period of 3 years $[17,18]$. This ever-increasing demand growth leads to more complex and less secure transmission network operations than before. Transmission expansion to relieve congestion can be costly in terms of installation and environmental costs. ESS installation can provide a viable solution that enables discharging of devices during peak hours to cater for line stability [19], thereby deferring transmission upgrades.

\subsubsection{Distribution Services}

The current increasing pace of RE is predominantly operating either under grid-connected or islanded operation modes in local distribution networks. RE power systems are usually installed in remote areas due to inefficient grid connectivity. Fluctuating output power from these sources can cause voltage instability and can damage system equipment. Moreover, low-voltage ride through is a problem caused by voltage collapse at the point of common coupling between the generator and grids, thereby causing highly limited dc power transfer. Trapped power in particular can cause severe overvoltage and can harm bus capacitors [20]. Therefore, voltage control by utilising system components to maintain voltages on lines within the required limit is necessary [21]. An ESS can 
participate in voltage regulation by compensating reactive power to stabilise the system [22]. An ESS also can provide additional support for heavily loaded local feeders.

\subsubsection{Energy Management Services}

Power quality distortion refers to the existence of harmonics in bus voltages and load current that can affect the sensitivity of some equipment [23]. Consequently, great power losses occur, and system efficiency decreases. An ESS can be integrated into Flexible Alternating Current Transmission System (FACTS) devices to compensate reactive power to reduce these harmonic signals [24]. The use of ESSs can also mitigate problems generated by the dynamic behavior of RE generation whereby it can serve as a compensator unit [25]. Delivery of high-quality power therefore can improve power system reliability as a whole by providing a secure and sufficient supply.

\subsubsection{Ancillary Services}

Frequency regulation is a method that helps maintain a certain frequency level to achieve a balance between generation and load. ESSs can compensate for rapid output fluctuations by RE-integrated power systems. During transients, an ESS can dynamically adjust the grid frequency by stabilising the angular frequency [26]. High-energy ESSs are suitable for providing a spinning reserve service because they have a rapid time response to regulate the frequency to a desired level [20].

\subsection{Development of ESS Technologies and Their Real-Life Applications}

Research developments on ESSs were initiated back in the late 1990s. The IEA was firstly established to coordinate oil price amongst its participants. Later, they initiated an electric storage programme, namely, Annex IX. The pioneering countries during the early foundation were mainly in Europe and Americas [9]. At present, many strong economic playmakers are investing in ESS installations for their power grids, indicating that ESS has created a large market as a highly viable electronic power system. Reference [27] elaborates the development of ESSs in both the currently largest economy playmakers, which are the USA and China. In 2015, the USA annual energy storage market grew by $243 \%$ with more than 21 GW of ESSs installed. Compared to the USA, China invested a cumulative capacity of $22.85 \mathrm{GW}$ in ESS in 2015 [27]. However, most of China's ESS projects are still in the demonstration phase, while the USA has operated most of their installed ESSs. According to [28], Germany is the leading country for RE installation with a target of above $60 \%$ of total energy production by 2030 . Since ESS technologies are currently developed to solve renewable output power fluctuation issues, ESSs are therefore expected to grow alongside this large development. From these examples, we can conclude that the ESS market is growing globally and is expected to expand in the future. We will discuss the development of ESS technologies and their applications in participating countries in the following sections.

Currently, many types of ESS technologies coexist and are usually further classified on the basis of their functions, response time, and storage media. A widely used classification is based on the form of stored energy $[29,30]$. Mechanical ESSs can be subdivided into pumped hydro energy storage (PHES), compressed air energy storage (CAES), and flywheels. These mechanical ESS are readily available and operating for grid applications. Electrochemical ESSs refer to conventional, rechargeable, and flow batteries. Most batteries are also available for commercial use. Another ESS that undergoes a chemical process is the hydrogen fuel cell. Hydrogen fuel cells are different from batteries because they undergo reverse electrolysis and thus produce clean by-products. All the above-mentioned devices require conversion techniques to absorb or release energy from the grids. Contrary to these technologies, electrical devices, such as supercapacitors and superconducting magnetic energy storage (SMES), do not require any conversion. Supercapacitors are currently in the development phase, whilst SMES is readily available. The most widely utilised technology is PHES, followed by battery energy storage. PHES is the least costly option since it sustains a low-cost storage medium (water). However, due to its limited location availability, batteries are the current preferred choice [31]. 


\subsubsection{Pumped Hydro Energy Storage}

PHES is a mechanical device. Amongst other ESS technologies, PHES is the most mature and the largest commercially available. The general configuration of PHES consists of two water storage units with different elevations. Water is pumped to the top reservoir for storing purposes and is released to the lower reservoir during discharging [32]. Figure 2 obtained from [33] illustrates the general configuration of PHES, and Table 1 tabulates some of the operating PHES facilities across the globe $[7,10,34]$.

Table 1. Implementation of pumped hydro energy storage (PHES) in power networks.

\begin{tabular}{ccc}
\hline Plant Name & Country & Capacity \\
\hline Rocky River & USA & $32 \mathrm{MW}$ \\
Bath Country & USA & $3003 \mathrm{MW}$ \\
Okinawa Yanbaru & Japan & $\sim 30 \mathrm{MW}$ \\
Ikaria Island & Greece & $2.655 \mathrm{MW}$ \\
\hline
\end{tabular}

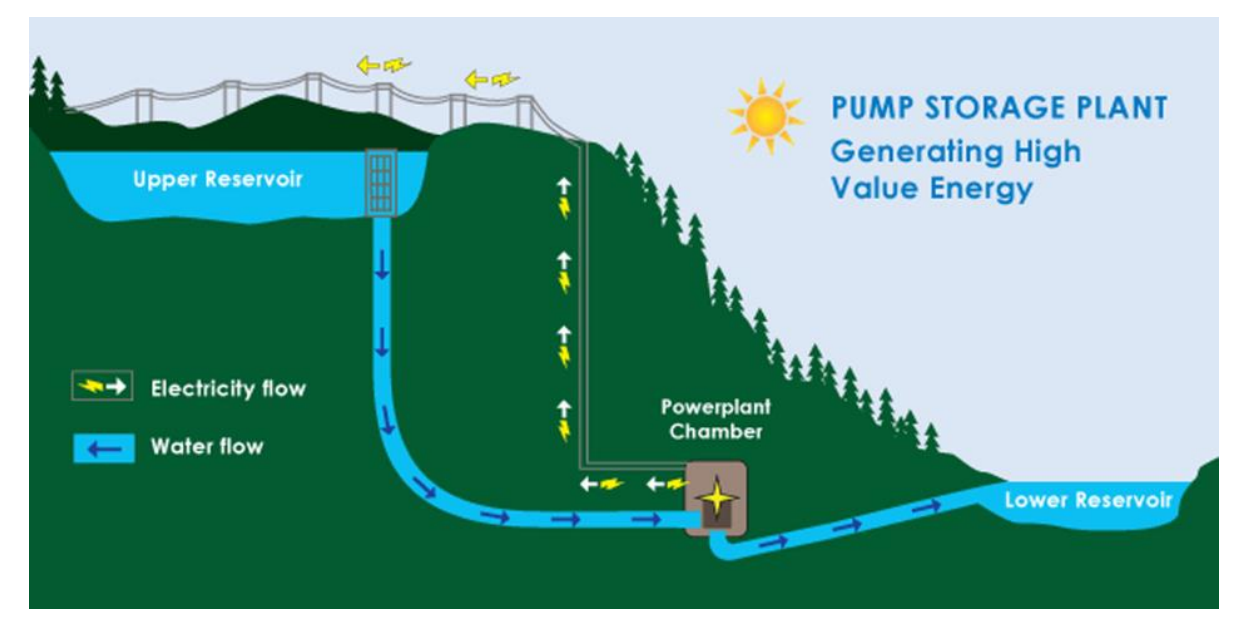

Figure 2. Configuration of a PHES.

\subsubsection{Flywheel Energy Storage}

Flywheel systems have gained considerable attention since decades ago with numerous experiments dating from the 1950s [35]. The flywheel is a mechanical ESS that stores energy from the grid and converts it to a spinning disc. This device accelerates the rotation to store energy and discharges by slowing down [20]. Flywheels can be applied to microgrids or can be hybridised with other ESS technologies, such as batteries, to improve efficiency [31]. Figure 3 obtained from [7] illustrates the components of a flywheel system, and Table 2 tabulates some of the operating applications of flywheels [36-39].

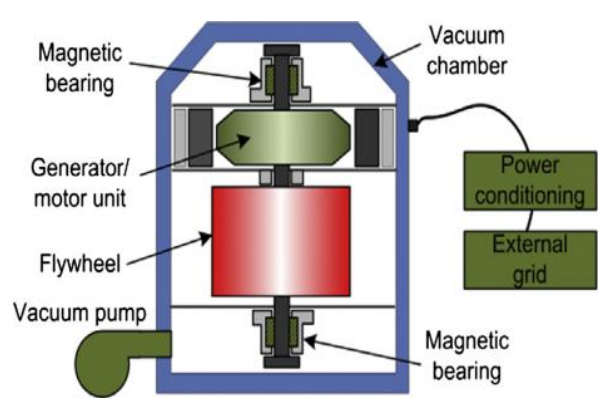

Figure 3. Schematic of a flywheel. 
Table 2. Manufacturers of flywheels and their application areas.

\begin{tabular}{cc}
\hline Company/Institute & Application Area \\
\hline Active Power Company & Back-up supply, uninterruptible power supply (UPS) \\
Beacon Power Company & Frequency regulation \\
Boeing Phantom Works & Peak shaving and power quality \\
Pillar Power System Ltd. & Voltage ride through and back-up supply \\
\hline
\end{tabular}

\subsubsection{Compressed Air Energy Storage}

CAES is also a mature ESS technology under the mechanical category. The concept of CAES is to compress air by using low-cost energy for storing and releasing the compressed air during discharge [16]. CAES has the lowest capital cost [16] and can store a large amount of energy with high efficiency. However, similar to those of PHES, their installations are limited due to geographical constraints. Currently, only two operating CAES plants are available. The first installed plant is located in Germany with a rated capacity of $290 \mathrm{MW}$. The second commercialised plant, located in the USA, has improved its cycling efficiency from $42 \%$ to $54 \%$ despite having a low-rated capacity of 110 MW [23]. Figure 4 obtained from [16] illustrates the schematic of a CAES facility.

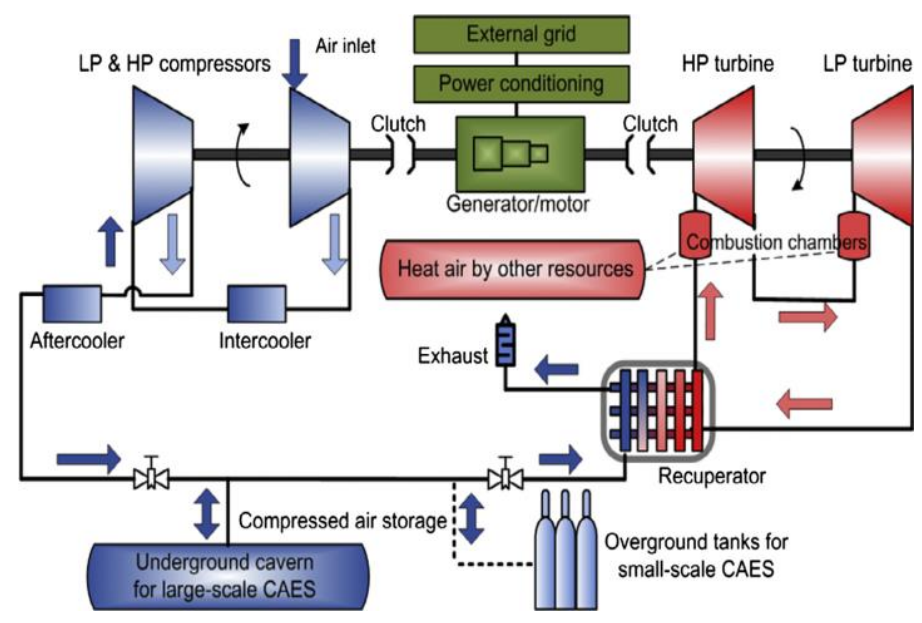

Figure 4. Schematic of compressed air energy storage (CAES).

\subsubsection{Battery Energy Storage System}

Battery ESSs (BESSs) are categorised as electrochemical devices that deliver electric energy by conversion of chemical reactions [32]. Power converters of BESSs are similar to those of wind turbines and photovoltaic (PV) systems; thus, they have an advantage in terms of flexibility [40]. BESSs can be classified as primary and secondary batteries. Primary batteries refer to non-rechargeable batteries, whereas secondary batteries refer to rechargeable batteries [23]. However, only rechargeable batteries are utilised for power grid applications. Batteries were rarely used in early years due to their low energy density and short lifetime [41]. However, current advancements in batteries have attracted investors to install BESSs due to the high energy density and simple means of installations.

Secondary batteries can be further classified into conventional and flow batteries. Conventional batteries are referred to as BESSs, whereas flow batteries are referred to separately. BESSs, which are commonly used for current utility grid applications, are lead acid and lithium-based batteries [40]. During discharging, electricity is generated through electrochemical processes. By contrast, electricity is converted into a chemical form by a reverse electrochemical process during charging [23]. Figure 5 obtained from [30] illustrates basic components of BESSs. BESSs consist of batteries, control, and a power conditioning system (C-PCS), whilst the remaining part comprises protection devices. BESSs have 
a wide range of applications due to the ease of installation and cost effectiveness. Table 3 tabulates the applications of BESSs in certain locations [10,30,42,43]. Advancements in research have made it possible to develop and deploy electric vehicles (EVs) for energy storage applications. Vehicle-to-grid (V2G) capability in EVs has shifted to a new paradigm in smart home and smart grid solutions. Generally, EV users can charge their vehicles at homes or public parking lots. When EVs are parked, a remarkable amount of power can be injected from the batteries of EVs into the grid during emergency conditions [44]. Currently, sodium nickel chloride batteries are developed for EVs [10].

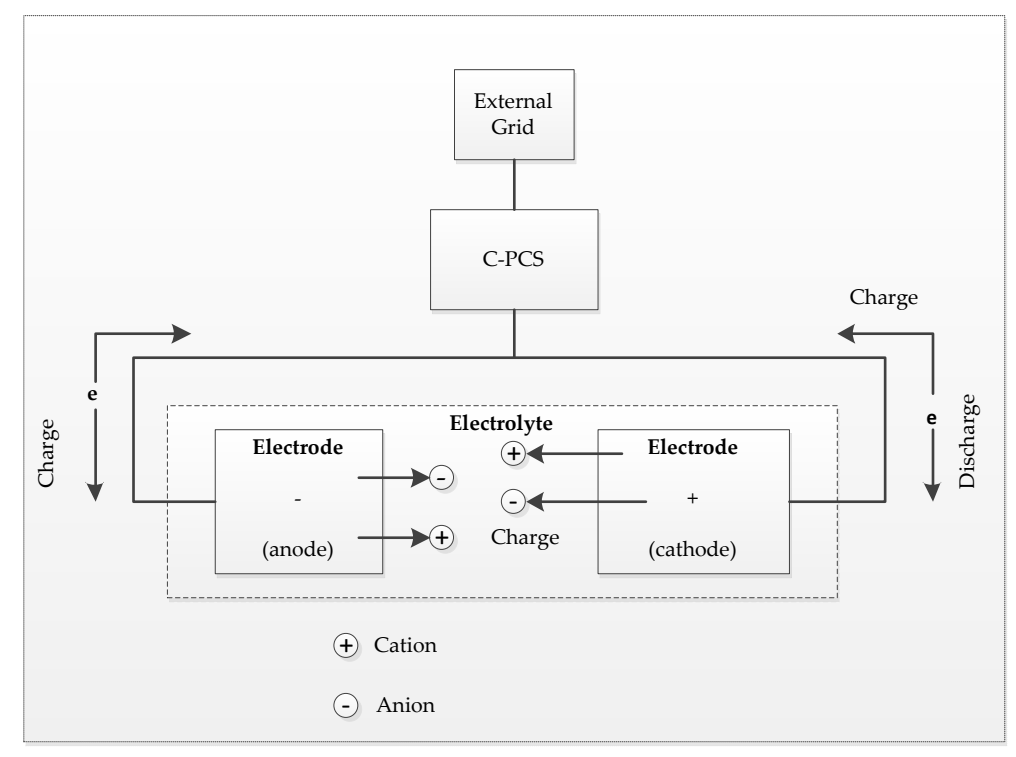

Figure 5. Schematic of a battery ESS (BESS).

Table 3. Distribution of battery energy storage systems (BESSs) and their applications.

\begin{tabular}{ccc}
\hline Locations & Rated Capacity & Applications \\
\hline Berlin & $8.5 \mathrm{MWh}$ & Frequency control \\
California & $40 \mathrm{MWh}$ & Load levelling \\
Puerto Rico & $1.4 \mathrm{MWh}$ & Spinning reserve \\
Hawaii & $3.75 \mathrm{MWh}$ & Power management \\
\hline
\end{tabular}

Flow batteries are newly invented power electronic devices that are different from conventional batteries due to their configuration characteristics. Unlike conventional batteries, flow batteries have separate tanks containing electrolytes [23]. The electrolytes are active reactants with a reversible capability to generate electricity [19]. Figure 6 obtained from [45] illustrates the operation of a flow battery. Vanadium redox batteries (VRBs) are the most preferred choice of flow battery technology due to their flexibility in offering numerous applications [10]. Table 4 tabulates some of the services offered by VRBs installed in certain countries [42,46-48].

Table 4. Distribution of vanadium redox batteries (VRBs) and their applications.

\begin{tabular}{ccc}
\hline Country & Rated Capacity & Applications \\
\hline Australia & $800 \mathrm{kWh}$ & Mitigation of wind power fluctuations \\
Ireland & $12 \mathrm{MWh}$ & Grid integration \\
Japan & $3 \mathrm{MWh}$ & Power quality tool \\
US & $2 \mathrm{MWh}$ & Load shifting \\
\hline
\end{tabular}




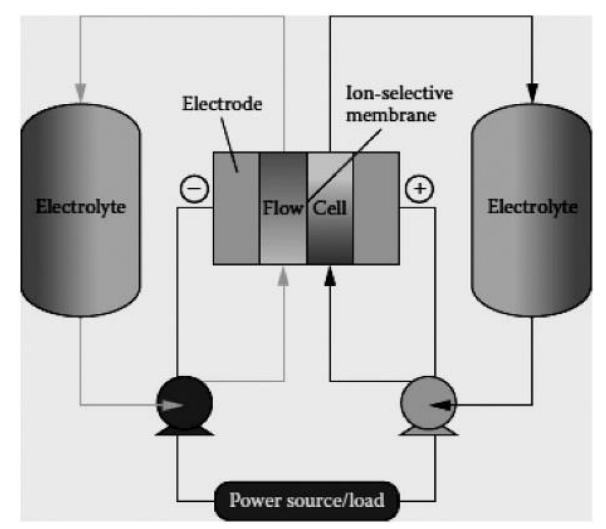

Figure 6. Configuration of a vanadium redox batterie (VRB).

\subsubsection{Fuel Cells}

Fuel cells are also under the same category as batteries. The features of a fuel cell are similar to those of a battery; however, they differ in their mode of operation, in the sense that a fuel cell consumes fuel to generate electricity. Specifically, it predominantly consumes hydrogen and other hydrocarbons to generate electricity $[7,19]$. This device is gaining considerable interest amongst researchers due to its cleanliness, cost effectiveness, and high efficiency [49]. A fuel cell can be integrated with an electrolyser unit to form a regenerative fuel cell and can thus convert electricity into hydrogen to store the energy for future use. Figure 7 obtained from [50] illustrates the operation of a regenerative fuel cell. Currently, hydrogen fuel cells are in the evaluation and demonstration stage. The first utility-scale test of hydrogen cells took place in Norway to test their reliability with an RE-integrated stand-alone power system [51].

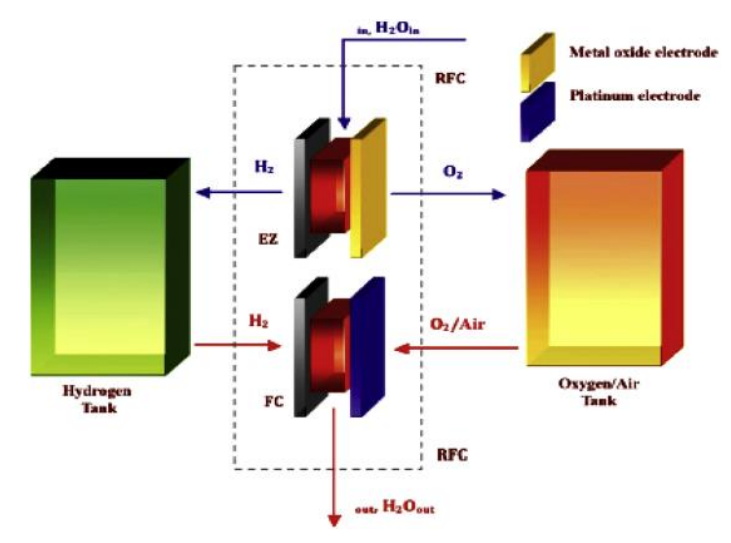

Figure 7. Configuration of a hydrogen-based fuel cell.

\subsubsection{Supercapacitors}

Most supercapacitors are known as direct storage because they store electric energy by means of liquid electrolyte solution between two conductors instead of common dielectric surfaces [10]. However, there also exist supercapacitors which fall under the electrochemical category, such as batteries. Figure 8 obtained from [30] illustrates a schematic of a supercapacitor. The advantage of this device is its capability to store a twofold-larger amount of energy capacity than a conventional capacitor [52]. Hence, this technology has been rapidly advanced in recent years. Table 5 tabulates some of the countries that manufacture this technology [42,53]. 
Table 5. Distribution of supercapacitors and their applications.

\begin{tabular}{cc}
\hline Country & Applications \\
\hline USA & Uninterruptible power supply \\
Japan & Power quality tool \\
Germany & Metro distribution \\
\hline
\end{tabular}

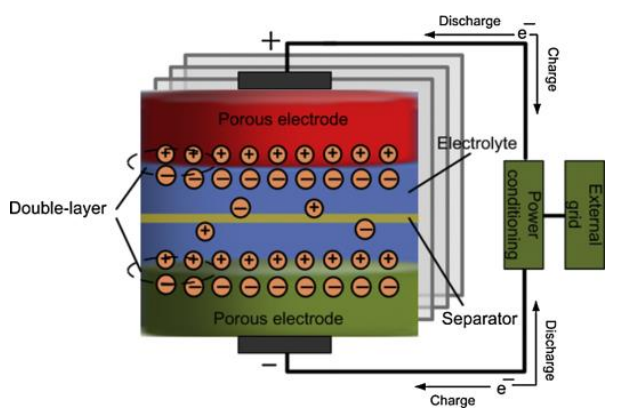

Figure 8. Schematic of a supercapacitor.

\subsubsection{Superconducting Magnetic Energy Storage}

SMES was firstly introduced in the 1970s [54]. An SMES device is an electrical device that can store energy in the form of a magnetic field induced by dc current flowing through the magnetic coils. Given that energy is stored in the form of current, energy can be drawn nearly instantaneously to give an extra advantage for SMES in terms of rapid time response [55]. Figure 9 obtained from [16] illustrates a schematic of SMES. SMES has wide applications and is predicted to become a viable choice in the future. However, the costly installation of SMES limits its significant contributions to improving the power quality of a system. Table 6 provides the distribution of SMES applications in certain locations [42,56,57].

Table 6. Distribution of superconducting magnetic energy storage (SMES) and their applications.

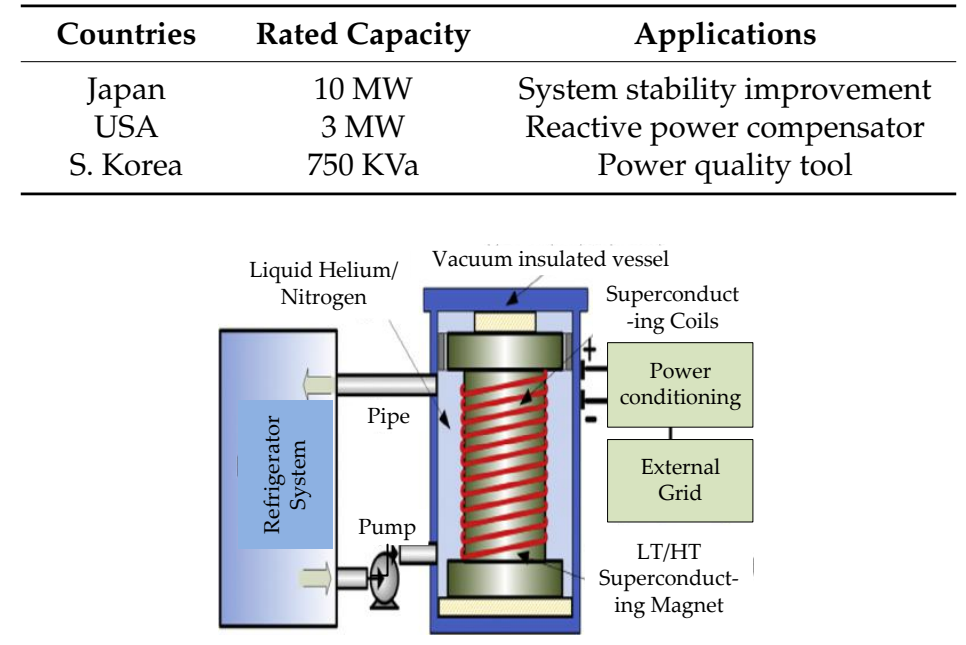

Figure 9. Schematic of superconducting magnetic energy storage (SMES).

\section{Reliability Impacts of ESSs on Power System Reliability}

\subsection{Concept of Power System Reliability}

The development of power systems has expanded over the decades. The main concern of electric power utility companies is to provide uninterruptible power supply to end loads all the time, but this 
implementation is still not practiced in real situations. Hence, utilities strive for ways that consider costs and reliability in an effective manner [58]. Reliability evaluation involves consideration of system states and determines whether they are adequate or secure [59]. Adequacy is defined as sufficient energy supplied within the system to be supplied to consumers, whereas security involves consideration of disturbance within the system [58]. Unlike security division, adequacy responds to static conditions and thus neglects the impacts of system disturbances.

Electric power systems are extremely complex and large. Thus, even current high-tech computers cannot analyse a power system as a single entity in a completely realistic manner. Therefore, the system is divided into three distinguished subsystems that can be analysed separately. The concept of hierarchical levels (HLs) has been developed to obtain a consistent means of identifying these subsystems. HL1 refers to generation facilities and their ability to supply energy adequately to end loads. HL2 refers to the composite generation and transmission and its ability to feed energy to the bulk supply points. Lastly, HL3 refers to a complete system, including distribution, and its ability to supply the demand of individual consumers [60]. Figure 10 illustrates the HL as a relevant referring point of reliability studies to date.

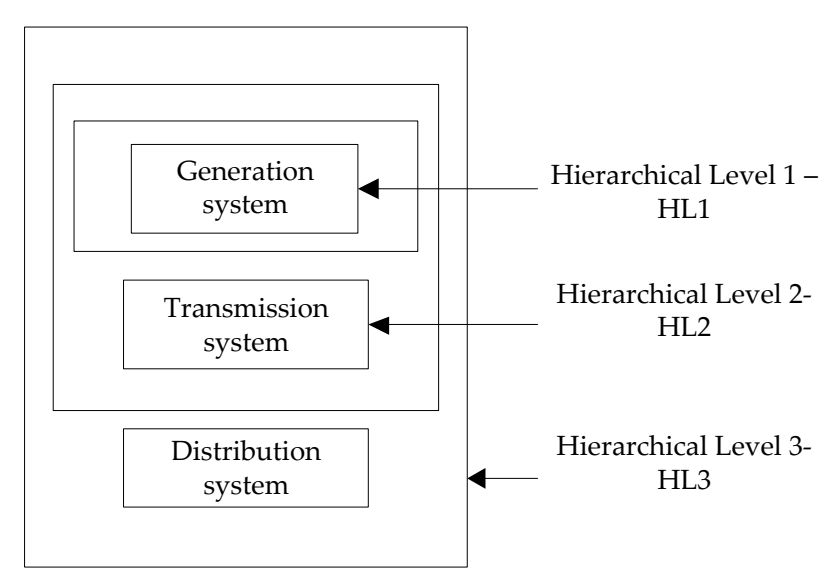

Figure 10. Hierarchical level (HL) in power system reliability studies.

\subsection{Utilisation of ESSs in Improving Power System Reliability}

In this section, a number of research articles related to contributions of ESSs to improving power system reliability are highlighted. We select 54 related articles, which we further classify in accordance with the type of energy source integrated with ESSs. Depending on the functionality of the ESS, energy storage can serve as either a conventional or RE source.

\subsubsection{Conventional Energy}

Conventional energy is non-renewable and is mainly extracted from fossil fuels. According to [5], fossil fuels contribute approximately $85 \%$ of global energy demand. However, excessive fossil fuel consumption leads to the decrease in fossil fuel reserves, highly fluctuating oil price, and global climate change [61]. Therefore, researchers are seeking for alternatives to mitigate these problems. One of the solutions is the utilisation of ESSs. ESSs have a wide range of applications that can help mitigate the aforementioned concerns from overconsumption of conventional energy, such as peak shaving and demand-side management. Table 7 highlights several studies related to the benefits of ESSs for fossil-fuel-dependent power systems. 
Table 7. Notable works of ESS utilization in conventional power systems.

\begin{tabular}{ccll}
\hline Source & HL & \multicolumn{1}{c}{ Contribution } & \multicolumn{1}{c}{ Limitation(s) } \\
\hline$[62]$ & HL3 & $\begin{array}{l}\text { Proposes an integration of real-time thermal rating } \\
\text { (RTTR) with ESS to further improve system reliability. }\end{array}$ & $\begin{array}{l}\text { May extend research by proposing methods } \\
\text { to optimize nodal siting of RTTR. }\end{array}$ \\
\hline [63] & HL3 & $\begin{array}{l}\text { Proposes a technique to improve economic operation } \\
\text { based on the hourly variable electricity price on } \\
\text { substation nodes. }\end{array}$ & $\begin{array}{l}\text { Does not specify consideration for forced } \\
\text { outage rate of system components. }\end{array}$ \\
\hline$[64]$ & HL3 & $\begin{array}{l}\text { Proposes an optimization technique of ESS sizing and } \\
\text { siting for reliability improvement in } \\
\text { distribution networks. }\end{array}$ & $\begin{array}{l}\text { May extend research by proposing a } \\
\text { method to optimize nodal siting of ESS. }\end{array}$ \\
\hline$[65]$ & HL2 & $\begin{array}{l}\text { Proposes a multistage generation expansion planning } \\
\text { and ESS scheduling to minimize net costs. }\end{array}$ & $\begin{array}{l}\text { Does not specify consideration for forced } \\
\text { outage rate of system components. }\end{array}$ \\
\hline [66] & HL3 & $\begin{array}{l}\text { Proposes an implementation of vehicle-to-grid under } \\
\text { battery exchange (BE) mode. }\end{array}$ & $\begin{array}{l}\text { May extend research by optimally sizing BE } \\
\text { station capacity to improve reliability } \\
\text { between consumers and utility companies. }\end{array}$ \\
\hline
\end{tabular}

\subsubsection{Renewable Energy}

The utilization of renewable sources for electric power supply has received increasing attention due to global environmental concerns associated with conventional energy generation [67]. In conventional generation systems, the generated energy must be consumed instantaneously; otherwise, it will be wasted. Intermittency of RE sources also causes high fluctuations in the power generated by these types. Therefore, ESSs are introduced to mitigate these problems by storing energy during low demand and supplying energy during peak demand.

From the selected articles, we obtain 49 articles related to the utilization of ESSs for RE-integrated power systems. Related RE sources are wind and solar along with hybrid RE resources. Hybrid RE resources refer to multiple renewable resources integrated into the power system.

Amongst all papers reviewed, most papers focus on the utilization of ESSs in wind-integrated power systems. According to [68], wind energy ranks second after hydroelectric energy in terms of installed capacity and is experiencing rapid growth. For a transmission network, wind energy contribution is restricted to a certain percentage of system load to maintain system stability from sudden change in output power of wind generation. For reliability studies, wind energy is usually modelled by considering its intermittency, and wind speed is assumed to change hourly. Various techniques have been proposed to model wind energy, which is usually modelled using the auto-regressive moving average (ARMA) model or the Weibull function. The ARMA model generates random wind speed as an ARMA model [69]. By contrast, the Weibull distribution considers wind speed, shape factor, and scale factor [70]. Other models are also applied, such as the Rayleigh probability distribution function (PDF) [71] and available capacity probability tables [72]. Table 8 shows articles related to the contribution of ESS to wind-integrated power systems. 
Table 8. Notable works of ESS utilization in wind-integrated power systems.

\begin{tabular}{|c|c|c|c|}
\hline Source & HL & Contribution & Limitation(s) \\
\hline [73] & HL3 & $\begin{array}{l}\text { Proposes an integration of tactical and operational management } \\
\text { for energy arbitrage and reliability improvement. }\end{array}$ & $\begin{array}{l}\text { Does not specify consideration for forced outage rate of } \\
\text { system components. }\end{array}$ \\
\hline [74] & HL3 & $\begin{array}{l}\text { Presents an optimization of storage reserve sizing that considers } \\
\text { minimization of system costs. }\end{array}$ & $\begin{array}{l}\text { Does not specify consideration for forced outage rate of } \\
\text { system components. }\end{array}$ \\
\hline [75] & HL1 & $\begin{array}{l}\text { Proposes a reliability assessment of ESS in a wind-integrated } \\
\text { power system for the case of Jeju Island. }\end{array}$ & $\begin{array}{l}\text { May extend research by proposing a method to optimize } \\
\text { ESS sizing. }\end{array}$ \\
\hline [76] & HL3 & $\begin{array}{l}\text { Proposes the reliability evaluations of mobile BESSs on } \\
\text { distribution networks. }\end{array}$ & May extend research by including sensitivity studies. \\
\hline [71] & HL3 & $\begin{array}{l}\text { Proposes an optimization technique of ESS sizing and nodal siting } \\
\text { whilst minimizing system total costs. }\end{array}$ & $\begin{array}{l}\text { May extend research by considering fluctuating costs of diesel } \\
\text { consumption. }\end{array}$ \\
\hline [77] & HL3 & $\begin{array}{l}\text { Presents an optimal sizing solution for ESS on a stand-alone } \\
\text { wind-integrated power system. }\end{array}$ & $\begin{array}{l}\text { Does not specify consideration for forced outage rate of } \\
\text { system components. }\end{array}$ \\
\hline [78] & HL2 & $\begin{array}{l}\text { Proposes a stochastic method to consider the fluctuation in RE } \\
\text { output power. }\end{array}$ & $\begin{array}{l}\text { Does not specify consideration for forced outage rate of } \\
\text { system components. }\end{array}$ \\
\hline [72] & HL3 & $\begin{array}{l}\text { Proposes an analytical model for reliability evaluation of ESS } \\
\text { whilst optimally minimizing system net costs. }\end{array}$ & May consider fluctuating costs of diesel in future research. \\
\hline [79] & HL3 & $\begin{array}{l}\text { Proposes a technique of integrating ESS with dynamic } \\
\text { network reconfiguration. }\end{array}$ & $\begin{array}{l}\text { Does not specify consideration for forced outage rate of } \\
\text { system components. }\end{array}$ \\
\hline [80] & HL3 & $\begin{array}{l}\text { Presents an innovative operating strategy for a distribution } \\
\text { network utilizing model predictive control. }\end{array}$ & $\begin{array}{l}\text { May extend research by sizing the capacity of wind and } \\
\text { ESS optimally. }\end{array}$ \\
\hline [81] & HL2 & $\begin{array}{l}\text { Proposes a reliability assessment to determine the adequate size } \\
\text { of ESS whilst considering the need for transmission upgrade. }\end{array}$ & $\begin{array}{l}\text { Does not specify consideration for forced outage rate of } \\
\text { system components. }\end{array}$ \\
\hline [82] & HL1 & $\begin{array}{l}\text { Conducts a range of studies to evaluate reliability impacts of } \\
\text { wind and hydro coordination. }\end{array}$ & $\begin{array}{l}\text { May extend research to determine reservoir } \\
\text { capacities optimally. }\end{array}$ \\
\hline [83] & HL3 & $\begin{array}{l}\text { Proposes a method to determine the economic point of wind } \\
\text { energy capacity whilst improving reliability. }\end{array}$ & $\begin{array}{l}\text { Does not specify consideration for ESS constraints, such as the } \\
\text { maximum rate of charging and discharging. }\end{array}$ \\
\hline [84] & HL2 & $\begin{array}{l}\text { Proposes an evaluation of reliability impacts of ESS with an } \\
\text { intelligent operating strategy. }\end{array}$ & $\begin{array}{l}\text { May extend research by including cost-benefit whilst } \\
\text { considering customer interruption costs. }\end{array}$ \\
\hline [85] & HL3 & Presents a stochastic capacity expansion planning of a microgrid. & $\begin{array}{l}\text { May extend research by including associated cost, such as } \\
\text { equipment transportation each time the system is upgraded. }\end{array}$ \\
\hline [86] & HL2 & $\begin{array}{l}\text { Evaluates the impacts of PHES on effective deferring of } \\
\text { transmission line expansions. }\end{array}$ & $\begin{array}{l}\text { The proposed planning method is intended for future } \\
\text { expansion of } 10 \text { years to come. Thus, future study may include } \\
\text { consideration of component price change within the period. }\end{array}$ \\
\hline [87] & HL3 & Evaluates a reliability constraint of optimal ESS capacity sizing. & May extend research by including optimal nodal siting of ESS. \\
\hline [88] & HL3 & $\begin{array}{l}\text { Proposes an integration of demand response program with ESS to } \\
\text { reduce total costs and improve reliability. }\end{array}$ & $\begin{array}{l}\text { Does not specify consideration for ESS constraints, such as the } \\
\text { maximum charging and discharging rates of the battery. }\end{array}$ \\
\hline [89] & HL3 & Proposes a dispatch strategy to determine optimal ESS capacity. & May extend research by adding unit operational constraints. \\
\hline [90] & HL3 & $\begin{array}{l}\text { Includes the cost of energy not supplied whilst optimizing the } \\
\text { total cost of the system. }\end{array}$ & $\begin{array}{l}\text { Does not specify consideration for forced outage rate of } \\
\text { system components. }\end{array}$ \\
\hline [91] & HL1 & $\begin{array}{l}\text { Investigates the amount of RE capacity to replace conventional } \\
\text { generation with the aid of PHES. }\end{array}$ & May extend research by optimizing ESS sizing. \\
\hline [92] & HL2 & $\begin{array}{l}\text { Presents a probabilistic optimal power flow for optimal sizing of } \\
\text { the capacity of ESS and for nodal siting of ESS. }\end{array}$ & $\begin{array}{l}\text { May extend research by considering fluctuating costs of } \\
\text { conventional generation. }\end{array}$ \\
\hline [93] & HL1 & $\begin{array}{l}\text { Proposes a method to determine the unit commitment of a power } \\
\text { system with PHES. }\end{array}$ & $\begin{array}{l}\text { Does not consider uncertainty caused by fluctuating wind } \\
\text { output power. }\end{array}$ \\
\hline [94] & HL3 & $\begin{array}{l}\text { Proposes a method to determine the size of batteries based on loss } \\
\text { of load probability (LOLP). }\end{array}$ & $\begin{array}{l}\text { Applies a nonsequential Monte Carlo simulation that does not } \\
\text { recognize fluctuations of wind output power. }\end{array}$ \\
\hline [95] & HL1 & $\begin{array}{l}\text { Proposes an analytical method to assess the reliability of a } \\
\text { wind-integrated power system. }\end{array}$ & $\begin{array}{l}\text { May extend research by proposing optimization methods on } \\
\text { ESS sizing and siting. }\end{array}$ \\
\hline [96] & HL3 & $\begin{array}{l}\text { Proposes a cost/worth evaluation of ESS on a wind-integrated } \\
\text { power system. }\end{array}$ & May extend research by considering fluctuating costs of diesel. \\
\hline
\end{tabular}

Solar energy is also gaining considerable interest because the source is abundant and inexhaustible. Solar energy is usually extracted using PV technology, which directly converts solar energy into electrical energy. A familiar solar generation technique is the Hybrid Optimization of Multiple Electric Renewables (HOMER) simulation program, developed by the National Renewable Energy Laboratory to generate hourly solar radiation at specific locations [97]. The reliability configuration of PV cells can also be modelled on the basis of other techniques, such as total cross-tied configuration [98], statistical modelling of beta, and Weibull and log normal functions [99]. Table 9 highlights studies related to ESS contributions to solar-integrated power systems. 
Table 9. Notable works of ESS utilization in solar-integrated power systems.

\begin{tabular}{ccll}
\hline Source & HL & \multicolumn{1}{c}{ Contribution(s) } & \multicolumn{1}{c}{ Limitation(s) } \\
\hline [100] & HL1 & $\begin{array}{l}\text { Proposes a reliability evaluation of ESS on a stand-alone } \\
\text { solar power system. }\end{array}$ & $\begin{array}{l}\text { Does not specify consideration for forced outage rate } \\
\text { of system components. }\end{array}$ \\
\hline [101] & HL3 & $\begin{array}{l}\text { Presents a cost-benefit analysis in a microgrid integrated } \\
\text { with ESS and solar energy. }\end{array}$ & Does not specify modelling techniques of solar power. \\
\hline [98] & HL3 & $\begin{array}{l}\text { Presents a probabilistic approach to determine adequacy } \\
\text { in a stand-alone solar power system. }\end{array}$ & $\begin{array}{l}\text { May extend research by sizing the capacity of } \\
\text { ESS optimally. }\end{array}$ \\
\hline [99] & HL3 & $\begin{array}{l}\text { Presents an optimization technique to size a stand-alone } \\
\text { solar power system integrated with batteries. }\end{array}$ & $\begin{array}{l}\text { Does not specify consideration for forced outage rate } \\
\text { of system components. }\end{array}$ \\
\hline [102] & HL3 & $\begin{array}{l}\text { Presents a multi-objective optimization technique to } \\
\text { minimize operational costs whilst improving reliability. }\end{array}$ & $\begin{array}{l}\text { Does not specify consideration for forced outage rate } \\
\text { of system components. }\end{array}$ \\
\hline [103] & HL3 & $\begin{array}{l}\text { Performs a reliability analysis of the contribution of ESS to } \\
\text { solar power system reliability. }\end{array}$ & $\begin{array}{l}\text { Applies a nonsequential Monte Carlo simulation that } \\
\text { does not recognize fluctuations in solar output power. }\end{array}$ \\
\hline [104] & HL3 & $\begin{array}{l}\text { Proposes a technique to calculate the size of batteries } \\
\text { based on LOLP. }\end{array}$ & $\begin{array}{l}\text { Applies a nonsequential Monte Carlo simulation that } \\
\text { does not recognize fluctuations in solar output power. }\end{array}$ \\
\hline & & &
\end{tabular}

Hybrid RE-integrated power systems are initiated to compensate for the shortcomings of other resources. They are usually adopted to supply energy for remote places and are isolated from utility grids, thereby forming their own microgrids. The most common hybrid unit is a solar-wind system due to the simple installation and mature technology advancement. Therefore, hybridization of solar and wind energy is a potential breakthrough for large-scale power systems, such as transmission and distribution networks [105]. Table 10 presents the selected articles on ESS contributions to hybrid solar-wind-integrated power systems.

Table 10. Notable works of ESS utilization in hybrid solar-wind-integrated power systems.

\begin{tabular}{|c|c|c|c|}
\hline Source & HL & Contribution(s) & Limitation(s) \\
\hline [44] & HL3 & $\begin{array}{l}\text { Proposes a reliability evaluation of an RE-integrated } \\
\text { power system with electric vehicle operating strategy. }\end{array}$ & $\begin{array}{l}\text { Applies a nonsequential Monte Carlo simulation that } \\
\text { ignores the fluctuations of solar and wind output power. }\end{array}$ \\
\hline [106] & HL3 & $\begin{array}{l}\text { Proposes a novel Cuckoo search method to size system } \\
\text { components optimally whilst minimizing costs. }\end{array}$ & $\begin{array}{l}\text { May extend research by including optimization of } \\
\text { nodal sizing. }\end{array}$ \\
\hline [107] & HL3 & $\begin{array}{l}\text { Presents particle swarm optimization (PSO) method to } \\
\text { size system components optimally. }\end{array}$ & $\begin{array}{l}\text { May extend research by including the effect of ESS } \\
\text { nodal siting. }\end{array}$ \\
\hline$[108]$ & HL3 & $\begin{array}{l}\text { Presents a stochastic approximation method to } \\
\text { optimize system components. }\end{array}$ & $\begin{array}{l}\text { May extend research by including the effect of ESS } \\
\text { nodal siting. }\end{array}$ \\
\hline [109] & HL3 & $\begin{array}{l}\text { Proposes different operating strategies of diesel } \\
\text { integrated into a hybrid RE system. }\end{array}$ & $\begin{array}{l}\text { Does not specify battery constraints, such as } \\
\text { charging/discharging constraints and } \\
\text { maximum/minimum capacity. }\end{array}$ \\
\hline$[110]$ & HL3 & $\begin{array}{l}\text { Uses loss of power supply probability to determine the } \\
\text { reliability of a stand-alone power system. }\end{array}$ & $\begin{array}{l}\text { Does not specify consideration for forced outage rate } \\
\text { of system components. }\end{array}$ \\
\hline [111] & HL2 & $\begin{array}{l}\text { Proposes an ESS optimal scheduling by considering } \\
\text { system reliability. }\end{array}$ & $\begin{array}{l}\text { May extend further research to size ESS } \\
\text { capacity optimally. }\end{array}$ \\
\hline [112] & HL3 & $\begin{array}{l}\text { Presents energy dispatch solutions by incorporating } \\
\text { power loss and reliability statistics. }\end{array}$ & $\begin{array}{l}\text { Does not specify consideration for forced outage rate } \\
\text { of system components. }\end{array}$ \\
\hline [113] & HL3 & $\begin{array}{l}\text { Presents a multi-objective PSO method to minimize } \\
\text { costs and improve reliability. }\end{array}$ & $\begin{array}{l}\text { Does not consider the uncertainty within wind speed, } \\
\text { solar radiation, and load demand. }\end{array}$ \\
\hline [114] & HL3 & $\begin{array}{l}\text { Presents an optimal expansion planning that aims to } \\
\text { maximize reliability and minimize costs. }\end{array}$ & $\begin{array}{l}\text { Implementation of interval linear programming can } \\
\text { overly estimate true solution bounds. }\end{array}$ \\
\hline [67] & HL3 & $\begin{array}{l}\text { Presents a reliability analysis of ESS on a power system } \\
\text { utilizing wind and/or solar energy. }\end{array}$ & $\begin{array}{l}\text { Does not specify the consideration for ESS constraints, } \\
\text { such as the maximum charging and discharging rates } \\
\text { of the battery. }\end{array}$ \\
\hline [115] & HL3 & $\begin{array}{l}\text { Presents a simulation method that extends well-being } \\
\text { analysis to RE. }\end{array}$ & $\begin{array}{l}\text { Does not specify the consideration for ESS constraints, } \\
\text { such as the maximum charging and discharging rates } \\
\text { of the battery. }\end{array}$ \\
\hline [116] & HL3 & $\begin{array}{l}\text { Presents a reliability evaluation of a microgrid } \\
\text { consisting of RE generation and ESS. }\end{array}$ & $\begin{array}{l}\text { Applies a nonsequential Monte Carlo simulation that } \\
\text { does not recognize fluctuations in RE output power. }\end{array}$ \\
\hline
\end{tabular}


The articles reviewed show that other renewable resources which can be hybridised are tidal, hydro, and biomass energy. However, these units are not commonly applied because their technology developments are still at the infancy stage. Therefore, they are not economic. In [117], ESS is integrated into a hybrid solar-wind-biomass-integrated power system. Operating strategies for supply-adequate microgrids considering real and reactive power are also proposed. Meanwhile, reference [118] assessed the reliability contribution of ESS to hybrid tidal-wind power systems. Reference [119] presented energy dispatch solutions by using ESS in a hybrid solar-wind-hydro-integrated power system. A hydro-plant model can be obtained from a Box-Muller distribution [120], and tidal energy can be modelled using the Wakeby distribution [118].

\section{Discussion}

This paper presents a comprehensive review on the development of ESS technologies and their applications. Different technologies are classified and analysed in accordance with their respective storage media. Their real-life applications are also presented. From the synthesised information, we conclude that ESSs are accepted by many countries as viable solutions for power system applications. However, their installations are mainly focused in Europe and North America, which are pioneers of the IEA Annex IX storage programme. Therefore, they have advanced research and development on storage systems. The Eastern Asia countries of China and Japan are also advancing, whereas other parts of the Asian continent remain unfamiliar with ESSs.

From the extracted papers, we observe that the application of energy storage in distribution networks is more prevalent than that in transmission networks. Microgrids are distribution networks that are mostly dedicated to serving isolated areas. However, advanced research on power systems in recent years has enabled interconnection of microgrids to distribution networks to form smart grids consisting of RE sources and ESSs. At present, other smart solutions, such as real-time thermal rating (RTTR) and demand-side management (DSM) integrated with ESS, have been developed to form highly reliable networks.

We also observe an increasing trend of utilising various techniques to optimise ESS, especially in terms of capacity sizing and nodal siting. Apart from these optimisation techniques, methods considering economic constraints are also introduced, such as model predictive control and stochastic dynamic programming. The trend is expected to continue to increase for maximising reliability optimally whilst minimising net costs.

\section{Conclusions and Potential Future Works}

Viewing the previous works on ESSs and power system reliability, we find shortcomings in the literature that future research can address. For instance, future research should more explore other renewable energy sources besides wind and solar energy. To the authors' best knowledge, modelling on other energy sources is limited. Therefore, future works can focus on developing accurate and efficient models of these sources to advance reliability studies.

Other than that, future research may consider reliability impacts of hybrid energy storage in modern power networks. Currently, hybrid energy storage is developing rapidly in terms of technological development. However, it is still not convincing enough to be implemented in real applications. For future works, researchers may study its impact on power system reliability to assist utility operators in decision-making.

Author Contributions: F.M. analyzed the data and wrote the paper; J.T. provided critical revisions and final approval of the version to be published; C.-M.L. and L.-R.C. managed the project.

Funding: This work is partly supported by the USM External Grant 304/PELECT/6050385 and USM Bridging Grant 304.PELECT.6316117, as well as, the Taiwan Ministry of Science and Technology Grant: MOST-107-2221-E-027-022-MY3 and MOST-107-2221-E-027-093-MY2

Conflicts of Interest: The authors declare no conflict of interest. 


\section{References}

1. WCED, S.W.S. World Commission on Environment and Development; Oxford University Press: London, UK, 1987.

2. Dincer, I.; Rosen, M.A. A worldwide perspective on energy, environment and sustainable development. Int. J. Energy Res. 1998, 22, 1305-1321. [CrossRef]

3. Dincer, I. Renewable energy and sustainable development: A crucial review. Renew. Sustain. Energy Rev. 2000, 4, 157-175. [CrossRef]

4. Akella, A.; Saini, R.; Sharma, M.P. Social, economical and environmental impacts of renewable energy systems. Renew. Energy 2009, 34, 390-396. [CrossRef]

5. Sen, S.; Ganguly, S. Opportunities, barriers and issues with renewable energy development-A discussion. Renew. Sustain. Energy Rev. 2017, 69, 1170-1181. [CrossRef]

6. Sen, S.; Ganguly, S.; Das, A.; Sen, J.; Dey, S. Renewable energy scenario in India: Opportunities and challenges. J. Afr. Earth Sci. 2016, 122, 25-31. [CrossRef]

7. Koohi-Kamali, S.; Tyagi, V.; Rahim, N.; Panwar, N.; Mokhlis, H. Emergence of energy storage technologies as the solution for reliable operation of smart power systems: A review. Renew. Sustain. Energy Rev. 2013, 25, 135-165. [CrossRef]

8. McLarnon, F.R.; Cairns, E.J. Energy Storage. Ann. Rev. Energy 1989, 14, 241-271. [CrossRef]

9. Baker, J.N.; Collinson, A. Electrical energy storage at the turn of the Millennium. Power Eng. J. 1999, 13, 107-112. [CrossRef]

10. Chen, H.; Cong, T.N.; Yang, W.; Tan, C.; Li, Y.; Ding, Y. Progress in electrical energy storage system: A critical review. Prog. Nat. Sci. 2009, 19, 291-312. [CrossRef]

11. Walawalkar, R.; Apt, J.; Mancini, R. Economics of electric energy storage for energy arbitrage and regulation in New York. Energy Policy 2007, 35, 2558-2568. [CrossRef]

12. Divya, K.C.; Østergaard, J. Battery energy storage technology for power systems-An overview. Electr. Power Syst. Res. 2009, 79, 511-520. [CrossRef]

13. Vazquez, S.; Lukic, S.M.; Galvan, E.; Franquelo, L.G.; Carrasco, J.M. Energy Storage Systems for Transport and Grid Applications. IEEE Trans. Ind. Electron. 2010, 57, 3881-3895. [CrossRef]

14. Billinton, R.; Allan, R.N.; Salvaderi, L. Applied Reliability Assessment in Electric Power Systems; IEEE: Piscataway, NJ, USA, 1991.

15. Xu, X.; Bishop, M.; Oikarinen, D.G.; Hao, C. Application and modeling of battery energy storage in power systems. CSEE J. Power Energy Syst. 2016, 2, 82-90. [CrossRef]

16. Amrouche, S.O.; Rekioua, D.; Rekioua, T.; Bacha, S. Overview of energy storage in renewable energy systems. Int. J. Hydrog. Energy 2016, 41, 20914-20927. [CrossRef]

17. Statistics, I. Key World Energy Statistics; International Energy Agency: Paris, France, 2014.

18. Publishing, O.; Staff, I.E.A.; Agency, I.E. $\mathrm{CO}_{2}$ Emissions from Fuel Combustion 2012; Organisation for Economic Co-operation and Development: Paris, France, 2012.

19. Suberu, M.Y.; Mustafa, M.W.; Bashir, N. Energy storage systems for renewable energy power sector integration and mitigation of intermittency. Renew. Sustain. Energy Rev. 2014, 35, 499-514. [CrossRef]

20. Farhadi, M.; Mohammed, O. Energy storage technologies for high-power applications. IEEE Trans. Ind. Appl. 2016, 52, 1953-1961. [CrossRef]

21. Chow, J.H.; De Mello, W.; Cheung, K.W. Electricity market design: An integrated approach to reliability assurance. Proc. IEEE 2005, 93, 1956-1969. [CrossRef]

22. Farrokhabadi, M.; Solanki, B.V.; Canizares, C.A.; Bhattacharya, K.; Koenig, S.; Sauter, P.S.; Leibfried, T.; Hohmann, S. Energy Storage in Microgrids: Compensating for Generation and Demand Fluctuations While Providing Ancillary Services. IEEE Power Energy Mag. 2017, 15, 81-91. [CrossRef]

23. Kousksou, T.; Bruel, P.; Jamil, A.; El Rhafiki, T.; Zeraouli, Y. Energy storage: Applications and challenges. Sol. Energy Mater. Sol. Cells 2014, 120, 59-80. [CrossRef]

24. Barrado, J.A.; Grino, R.; Valderrama-Blavi, H. Power-Quality Improvement of a Stand-Alone Induction Generator Using a STATCOM With Battery Energy Storage System. IEEE Trans. Power Deliv. 2010, 25, 2734-2741. [CrossRef]

25. Baroudi, J.A.; Dinavahi, V.; Knight, A.M. A review of power converter topologies for wind generators. Renew. Energy 2007, 32, 2369-2385. [CrossRef] 
26. Eckroad, S.; Gyuk, I. EPRI-DOE Handbook of Energy Storage for Transmission E Distribution Applications; Electric Power Research Institute, Inc.: Palo Alto, CA, USA, 2003; pp. 3-35.

27. Zhang, Y.; Gevorgian, V.; Wang, C.; Lei, X.; Chou, E.; Yang, R.; Li, Q.; Jiang, L. Grid-Level Application of Electrical Energy Storage: Example Use Cases in the United States and China. IEEE Power Energy Mag. 2017, 15, 51-58. [CrossRef]

28. Commission, I.E. Electrical Energy Storage White Paper; International Electrotechnical Commission: Geneva, Switzerland, 2011; pp. 1-78.

29. Beaudin, M.; Zareipour, H.; Schellenberglabe, A.; Rosehart, W. Energy storage for mitigating the variability of renewable electricity sources: An updated review. Energy Sustain. Dev. 2010, 14, 302-314. [CrossRef]

30. Díaz-González, F.; Sumper, A.; Gomis-Bellmunt, O.; Villafáfila-Robles, R. A review of energy storage technologies for wind power applications. Renew. Sustain. Energy Rev. 2012, 16, 2154-2171. [CrossRef]

31. Mahlia, T.; Saktisahdan, T.; Jannifar, A.; Hasan, M.; Matseelar, H. A review of available methods and development on energy storage; technology update. Renew. Sustain. Energy Rev. 2014, 33, 532-545. [CrossRef]

32. Huggins, R.A. Energy Storage; Springer: Berlin, Germany, 2010; Volume 391.

33. Aneke, M.; Wang, M. Energy storage technologies and real life applications-A state of the art review. Appl. Energy 2016, 179, 350-377. [CrossRef]

34. Arántegui, R.L.; Fitzgerald, N.; Leahy, P. Pumped-Hydro Energy Storage: Potential for Transformation from Single Dams; Technical Reports; JRC Scientific: Luxembourg, 2012.

35. Bahnfleth, W.P.; Song, J. Constant flow rate charging characteristics of a full-scale stratified chilled water storage tank with double-ring slotted pipe diffusers. Appl. Therm. Eng. 2005, 25, 3067-3082. [CrossRef]

36. Long, Z.; Zhiping, Q. Review of flywheel energy storage system. In Proceedings of ISES World Congress 2007 (Vol. I-Vol. V); Springer: Berlin/Heidelberg, Germany, 2008; pp. 2815-2819.

37. Pena-Alzola, R.; Sebastián, R.; Quesada, J.; Colmenar, A. Review of flywheel based energy storage systems. In Proceedings of the 2011 International Conference on Power Engineering, Energy and Electrical Drives (POWERENG), Malaga, Spain, 11-13 May 2011; pp. 1-6.

38. Hadjipaschalis, I.; Poullikkas, A.; Efthimiou, V. Overview of current and future energy storage technologies for electric power applications. Renew. Sustain. Energy Rev. 2009, 13, 1513-1522. [CrossRef]

39. Sebastián, R.; Peña Alzola, R. Flywheel energy storage systems: Review and simulation for an isolated wind power system. Renew. Sustain. Energy Rev. 2012, 16, 6803-6813. [CrossRef]

40. Lu, C.-F.; Liu, C.-C.; Wu, C.-J. Dynamic modelling of battery energy storage system and application to power system stability. IEE Proc. Gener. Transm. Distrib. 1995, 142, 429-435. [CrossRef]

41. Roberts, B. Capturing grid power. IEEE Power Energy Mag. 2009, 7. [CrossRef]

42. Zhang, W.-L.; Qiu, M.; Lai, X.-K. Application of energy storage technologies in power grids. Power Syst. Technol. 2008, 7, 3-9.

43. Hodson, H. Texas-Sized Battery Aims to Green up the Grid; Elsevier: New York, NY, USA, 2013.

44. Farzin, H.; Fotuhi-Firuzabad, M.; Moeini-Aghtaie, M. Reliability studies of modern distribution systems integrated with renewable generation and parking lots. IEEE Trans. Sustain. Energy 2017, 8, 431-440. [CrossRef]

45. Barnes, F.S.; Levine, J.G. Large Energy Storage Systems Handbook; CRC Press: Roca Raton, FL, USA, 2011.

46. Gonzalez, A.; Gallachoir, B.; McKeogh, E.; Lynch, K. Study of Electricity Storage Technologies and Their Potential to Address Wind Energy Intermittency in Ireland; Sustainable Energy Ireland: Dublin, Republic of Ireland, 2004.

47. Leung, P.; Li, X.; Ponce de Leon, C.; Berlouis, L.; Low, C.T.J.; Walsh, F.C. Progress in redox flow batteries, remaining challenges and their applications in energy storage. RSC Adv. 2012, 2, 10125-10156. [CrossRef]

48. Holzman, D.C. The vanadium advantage: Flow batteries put wind energy in the bank. Environ. Health Perspect. 2007, 115, A358. [CrossRef] [PubMed]

49. Erdinc, O.; Uzunoglu, M. Recent trends in PEM fuel cell-powered hybrid systems: Investigation of application areas, design architectures and energy management approaches. Renew. Sustain. Energy Rev. 2010, 14, 2874-2884. [CrossRef]

50. Carbone, R. Energy Storage in the Emerging Era of Smart Grids. Available online: https:/ /www.intechopen. com/books/energy-storage-in-the-emerging-era-of-smart-grids (accessed on 4 August 2018).

51. Nakken, T.; Strand, L.; Frantzen, E.; Rohden, R.; Eide, P. The Utsira wind-hydrogen system-operational experience. In European Wind Energy Conference; EWEC: Athens, Greece, 2006; pp. 1-9. 
52. Chen, H.; Ding, Y.; Peters, T.; Berger, F. Method of Storing Energy and a Cryogenic Energy Storage System. U.S. Patent Application No. 15/053,840, 23 June 2016.

53. Sharma, P.; Bhatti, T.S. A review on electrochemical double-layer capacitors. Energy Convers. Manag. 2010, 51, 2901-2912. [CrossRef]

54. Boom, R.; Peterson, H. Superconductive energy storage for power systems. IEEE Trans. Magn. 1972, 8, 701-703. [CrossRef]

55. Ribeiro, P.F.; Johnson, B.K.; Crow, M.L.; Arsoy, A.; Liu, Y. Energy storage systems for advanced power applications. Proc. IEEE 2001, 89, 1744-1756. [CrossRef]

56. Ali, M.H.; Wu, B.; Dougal, R.A. An Overview of SMES Applications in Power and Energy Systems. IEEE Trans. Sustain. Energy 2010, 1, 38-47. [CrossRef]

57. Hassenzahl, W.V.; Hazelton, D.W.; Johnson, B.K.; Komarek, P.; Noe, M.; Reis, C.T. Electric power applications of superconductivity. Proc. IEEE 2004, 92, 1655-1674. [CrossRef]

58. Lata, P.; Vadhera, S. Issues of concerns in power system reliability. In Proceedings of the 2015 International Conference on Power, Instrumentation, Control and Computing (PICC), Thrissur, India, 9-11 December 2015; pp. 1-6.

59. Bhavaraju, M. Composite system reliability evaluation. Int. J. Electr. Power Energy Syst. 1988, 10, 174-179. [CrossRef]

60. Billinton, R.; Allan, R.N. Power-system reliability in perspective. Electron. Power 1984, 30, 231-236. [CrossRef]

61. I. P. o. C. C. W. G. 3. Climate Change 2007: Mitigation: Contribution of Working Group III to the Fourth Assessment Report of the Intergovernmental Panel on Climate Change: Summary for Policymakers and Technical Summary; Cambridge University Press: Cambridge, UK, 2007.

62. Greenwood, D.M.; Wade, N.S.; Taylor, P.C.; Papadopoulos, P.; Heyward, N. A Probabilistic Method Combining Electrical Energy Storage and Real-Time Thermal Ratings to Defer Network Reinforcement. IEEE Trans. Sustain. Energy 2017, 8, 374-384. [CrossRef]

63. Shen, X.; Shahidehpour, M.; Han, Y.; Zhu, S.; Zheng, J. Expansion Planning of Active Distribution Networks With Centralized and Distributed Energy Storage Systems. IEEE Trans. Sustain. Energy 2017, 8, 126-134. [CrossRef]

64. Hedayat, S.; Reza, H.; Mehdi Ahmadi, J. Reliability improvement in radial electrical distribution network by optimal planning of energy storage systems. Energy 2015, 93, 2299-2312.

65. Reza, H.; Hedayat, S.; Mehdi Ahmadi, J. Multistage generation expansion planning incorporating large scale energy storage systems and environmental pollution. Renew. Energy 2016, 97, 636-645.

66. Cheng, L.; Chang, Y.; Lin, J.; Singh, C. Power System Reliability Assessment With Electric Vehicle Integration Using Battery Exchange Mode. IEEE Trans. Sustain. Energy 2013, 4, 1034-1042. [CrossRef]

67. Billinton, R. Impacts of energy storage on power system reliability performance. In Proceedings of the Canadian Conference on Electrical and Computer Engineering, Saskatoon, SK, Canada, 1-4 May 2005; pp. 494-497.

68. Panwar, N.; Kaushik, S.; Kothari, S. Role of renewable energy sources in environmental protection: A review. Renew. Sustain. Energy Rev. 2011, 15, 1513-1524. [CrossRef]

69. Karki, R.; Dhungana, D.; Billinton, R. An appropriate wind model for wind integrated power systems reliability evaluation considering wind speed correlations. Appl. Sci. 2013, 3, 107-121. [CrossRef]

70. Lun, I.Y.; Lam, J.C. A study of Weibull parameters using long-term wind observations. Renew. Energy 2000, 20, 145-153. [CrossRef]

71. Awad, A.S.A.; El-Fouly, T.H.M.; Salama, M.M.A. Optimal ESS allocation for load management application. IEEE Trans. Power Syst. 2015, 30, 327-336. [CrossRef]

72. Chengshan, W.; Bingqi, J.; Li, G.; Kai, Y.; Bing, S. Optimal planning of stand-alone microgrids incorporating reliability. J. Mod. Power Syst. Clean Energy 2014, 2, 195-205.

73. Azcárate, C.; Mallor, F.; Mateo, P. Tactical and operational management of wind energy systems with storage using a probabilistic forecast of the energy resource. Renew. Energy 2017, 102, 445-456. [CrossRef]

74. Dong, J.; Gao, F.; Guan, X.; Zhai, Q.; Wu, J. Storage-Reserve Sizing with Qualified Reliability for Connected High Renewable Penetration Micro-Grid. IEEE Trans. Sustain. Energy 2016, 7, 732-743. [CrossRef]

75. Oh, U.; Choi, J.; Kim, H.H. Reliability Contribution Function considering Wind Turbine Generators and Battery Energy Storage System in Power System. IFAC-PapersOnLine 2016, 49, 301-306. [CrossRef] 
76. Zheng, Y.; Dong, Z.; Huang, S.; Meng, K.; Luo, F.; Huang, J.; Hill, D. Optimal integration of mobile battery energy storage in distribution system with renewables. J. Mod. Power Syst. Clean Energy 2015, 3, 589-596. [CrossRef]

77. Kamble, K.M.; Jadhav, H.T. A wind-battery optimal design algorithm for power generation system. ARPN J. Eng. Appl. Sci. 2015, 10, 3566.

78. Shu, Z.; Jirutitijaroen, P. Optimal operation strategy of energy storage system for grid-connected wind power plants. IEEE Trans. Sustain. Energy 2014, 5, 190-199. [CrossRef]

79. Celli, G.; Ghiani, E.; Pilo, F.; Soma, G.G. Reliability assessment in smart distribution networks. Electr. Power Syst. Res. 2013, 104, 164-175. [CrossRef]

80. Xu, Y.; Singh, C. Adequacy and economy analysis of distribution systems integrated with electric energy storage and renewable energy resources. IEEE Trans. Power Syst. 2012, 27, 2332-2341. [CrossRef]

81. Zhang, Y.; Zhu, S.; Chowdhury, A.A. Reliability modeling and control schemes of composite energy storage and wind generation system with adequate transmission upgrades. IEEE Trans. Sustain. Energy 2011, 2, 520-526. [CrossRef]

82. Karki, R.; Hu, P.; Billinton, R. Reliability evaluation considering wind and hydro power coordination. IEEE Trans. Power Syst. 2010, 25, 685-693. [CrossRef]

83. Karaki, S.H.; Chedid, R.B.; Ramadan, R. Probabilistic production costing of diesel-wind energy conversion systems. IEEE Trans. Energy Convers. 2000, 15, 284-289. [CrossRef]

84. Xu, Y.; Singh, C. Power System Reliability Impact of Energy Storage Integration With Intelligent Operation Strategy. IEEE Trans. Smart Grid 2014, 5, 1129-1137. [CrossRef]

85. Hajipour, E.; Bozorg, M.; Fotuhi-Firuzabad, M. Stochastic Capacity Expansion Planning of Remote Microgrids With Wind Farms and Energy Storage. IEEE Trans. Sustain. Energy 2015, 6, 491-498. [CrossRef]

86. Hozouri, M.A.; Abbaspour, A.; Fotuhi-Firuzabad, M.; Moeini-Aghtaie, M. On the Use of Pumped Storage for Wind Energy Maximization in Transmission-Constrained Power Systems. IEEE Trans. Power Syst. 2015, 30, 1017-1025. [CrossRef]

87. Bahramirad, S.; Reder, W.; Khodaei, A. Reliability-Constrained Optimal Sizing of Energy Storage System in a Microgrid. IEEE Trans. Smart Grid 2012, 3, 2056-2062. [CrossRef]

88. Sayyad, N.; Majid, M.; Naser Nourani, E. An efficient cost-reliability optimization model for optimal siting and sizing of energy storage system in a microgrid in the presence of responsible load management. Energy 2017, 139, 89-97.

89. Tzu-Chieh, H.; John, C.; Kuei-Yuan, C. Reducing uncertainty accumulation in wind-integrated electrical grid. Energy 2017, 141, 1072-1083.

90. Sajad, T.; Seyed Saeedallah, M.; Taher, N. Stochastic scheduling of local distribution systems considering high penetration of plug-in electric vehicles and renewable energy sources. Energy 2017, 121, 480-490.

91. Andrzej, R.; Adam, W. Trends of changes in the power generation system structure and their impact on the system reliability. Energy 2015, 92 Pt 1, 128-134.

92. Ghofrani, M.; Arabali, A.; Etezadi-Amoli, M.; Fadali, M.S. Energy Storage Application for Performance Enhancement of Wind Integration. IEEE Trans. Power Syst. 2013, 28, 4803-4811. [CrossRef]

93. Tuohy, A.; Malley, M.O. Impact of pumped storage on power systems with increasing wind penetration. In 2009 IEEE Power \& Energy Society General Meeting; IEEE: Piscataway, NJ, USA, 2009; p. 1.

94. Liu, X.; Islam, S. Reliability Evaluation of a Wind-Diesel Hybrid Power System with Battery Bank Using Discrete Wind Speed Frame Analysis. In Proceedings of the 2006 International Conference on Probabilistic Methods Applied to Power Systems, Stockholm, Sweden, 11-15 June 2006; p. 1.

95. Gao, Z.Y.; Peng, W.; Jianhui, W. Impacts of energy storage on reliability of power systems with WTGs. In Proceedings of the 2010 IEEE 11th International Conference on Probabilistic Methods Applied to Power Systems, Singapore, 14-17 June 2010; p. 65.

96. Bagen, B.; Billinton, R. Reliability Cost/Worth Associated With Wind Energy and Energy Storage Utilization in Electric Power Systems. In Proceedings of the 10th International Conference on Probablistic Methods Applied to Power Systems, Rincon, Puerto Rico, 25-29 May 2008; p. 1.

97. Graham, V.; Hollands, K. A method to generate synthetic hourly solar radiation globally. Sol. Energy 1990, 44, 333-341. [CrossRef]

98. Koh, L.H.; Wang, P.; Choo, F.H.; Tseng, K.J.; Gao, Z.; Püttgen, H.B. Operational adequacy studies of a PV-based and energy storage stand-alone microgrid. IEEE Trans. Power Syst. 2015, 30, 892-900. [CrossRef] 
99. Fezai, S.; Belhadj, J. Optimal sizing of a stand-alone photovoltaic system using statistical approach. Int. J. Renew. Energy Res. 2014, 4, 329-337.

100. Wu, L.; Wen, C.; Ren, H. Reliability evaluation of the solar power system based on the Markov chain method. Int. J. Energy Res. 2017, 41, 2509-2516. [CrossRef]

101. Liu, W.; Niu, S.; Xu, H. Optimal planning of battery energy storage considering reliability benefit and operation strategy in active distribution system. J. Mod. Power Syst. Clean Energy 2017, 5, 177-186. [CrossRef]

102. Azizivahed, A.; Naderi, E.; Narimani, H.; Fathi, M.; Narimani, M.R. A New Bi-Objective Approach to Energy Management in Distribution Networks with Energy Storage Systems. IEEE Trans. Sustain. Energy 2018, 9, 56-64. [CrossRef]

103. Singh, S.S.; Fernandez, E. Reliability evaluation of a solar photovoltaic system with and without battery storage. In Proceedings of the 2015 Annual IEEE India Conference (INDICON), New Delhi, India, 17-20 December 2015; p. 1.

104. Singh, S.S.; Fernandez, E. Method for evaluating battery size based on loss of load probability concept for a remote PV system. In Proceedings of the 2014 6th IEEE Power India International Conference (PIICON), Delhi, India, 5-7 December 2014; p. 1.

105. Force, R.T. The IEEE reliability test system-1996. IEEE Trans. Power Syst 1999, 14, 1010-1020.

106. Sanajaoba, S.; Fernandez, E. Maiden application of Cuckoo Search algorithm for optimal sizing of a remote hybrid renewable energy System. Renew. Energy 2016, 96, 1-10. [CrossRef]

107. Fard, H.H.; Bahreyni, S.A.; Dashti, R.; Shayanfar, H.A. Evaluation of reliability parameters in micro-grid. Iran. J. Electr. Electron. Eng. 2015, 11, 127.

108. Arabali, A.; Ghofrani, M.; Etezadi-Amoli, M.; Fadali, M.S. Stochastic performance assessment and sizing for a hybrid power system of Solar/Wind/Energy Storage. IEEE Trans. Sustain. Energy 2014, 5, 363-371. [CrossRef]

109. Bagen, R.B. Evaluation of different operating strategies in small stand-alone power systems. IEEE Trans. Energy Convers. 2005, 20, 654-660. [CrossRef]

110. Yang, H.X.; Lu, L.; Burnett, J. Weather data and probability analysis of hybrid photovoltaic-wind power generation systems in Hong Kong. Renew. Energy 2003, 28, 1813-1824. [CrossRef]

111. Wook-Won, K.; Je-Seok, S.; Sung-Yul, K.; Jin, O.K. Operation scheduling for an energy storage system considering reliability and aging. Energy 2017, 141, 389-397.

112. Xinli, F.; Shihao, M.; Qiang, Y.; Jintao, Z. Cooperative energy dispatch for multiple autonomous microgrids with distributed renewable sources and storages. Energy 2016, 99, 48-57.

113. Baghaee, H.R.; Mirsalim, M.; Gharehpetian, G.B.; Talebi, H.A. Reliability/cost-based multi-objective Pareto optimal design of stand-alone wind/PV/FC generation microgrid system. Energy 2016, 115, 1022-1041. [CrossRef]

114. Mohammad Hadi Shaban, B.; Asghar Akbari, F. Stochastic-based resource expansion planning for a grid-connected microgrid using interval linear programming. Energy 2016, 113, 776-787. [CrossRef]

115. Bagen, R.B. Incorporating well-being considerations in generating systems using energy storage. IEEE Trans. Energy Convers. 2005, 20, 225-230. [CrossRef]

116. Carmen, L.T.B.; Eduardo, C. Microgrids Reliability Evaluation with Renewable Distributed Generation and Storage Systems. IFAC Proc. Vol. 2011, 44, 11695-11700.

117. Arefifar, S.A.; Mohamed, Y.A.R.I. DG Mix, Reactive Sources and Energy Storage Units for Optimizing Microgrid Reliability and Supply Security. IEEE Trans. Smart Grid 2014, 5, 1835-1844. [CrossRef]

118. Liu, M.; Li, W.; Yu, J.; Ren, Z.; Xu, R. Reliability evaluation of tidal and wind power generation system with battery energy storage. J. Mod. Power Syst. Clean Energy 2016, 4, 636-647. [CrossRef]

119. Nassourou, M.; Puig, V.; Blesa, J. Robust Optimization based Energy Dispatch in Smart Grids Considering Simultaneously Multiple Uncertainties: Load Demands and Energy Prices. IFAC-PapersOnLine 2017, 50, 6755-6760. [CrossRef]

120. Allan, R.; Roman, J. Reliability assessment of generation systems containing multiple hydro plant using simulation techniques. IEEE Trans. Power Syst. 1989, 4, 1074-1080. [CrossRef]

(C) 2018 by the authors. Licensee MDPI, Basel, Switzerland. This article is an open access article distributed under the terms and conditions of the Creative Commons Attribution (CC BY) license (http:/ / creativecommons.org/licenses/by/4.0/). 